\title{
LOWER LIP SQUAMOUS CELL CARCINOMA: A CASE REPORT OF SURGICAL TREATMENT WITH RECONSTRUCTION USING A BILATERAL BERNARD-WEBSTER FLAP
}

\author{
Rosen B. TSOLOV ${ }^{1 凶}$, Georgi Y. YORDANOV ${ }^{2}$ \\ ${ }^{1}$ Clinic of Maxillofacial Surgery, „St. George“ University Hospital, Plovdiv, Bulgaria \\ ${ }^{2}$ Department of Allergology, Physiotherapy and Clinical radiology, Faculty of Dental Medicine, Medical \\ University of Plovdiv, Bulgaria
}

Received 10 Mar 2020, Corrections received 02 Apr 2020, Accepted 04 May 2020

hitps://doi.org/10.31688/ABMU.2020.55.2.17

\begin{abstract}
Introduction. Although squamous cell carcinoma (SCC) is the most common oral cancer with distribution worldwide, the giant form of the disease is extremely rare, due to its easy detection and early diagnosis. The primary goal in tumor surgery is excision with borders clear of neoplasia. The second goal is aesthetics and function retention. The specific surgical approach is chosen according to the length, the thickness and the location of the lip defect.

Case presentation. We present the case of a patient with squamous cell carcinoma of the lower lip. In the reported case, the full thickness defect resulting from SCC excision, which affects more than one third of the length of the lower lip, had been reconstructed with the Bernard-Webster lid.
\end{abstract}

Conclusions. Although the etiologic factors for squamous cell carcinoma are well-known, new prognostic factors for tumor differentiation, such as $\beta$-catenin abnormal expression, and the negative impact on

\section{RÉsumé}

Le carcinome cellulaire squameux des lèvres inférieures: rapport de cas du traitement chirurgical avec reconstruction à l'aide d'un flambeau bilatéral Bernard-Webster

Introduction. Bien que le carcinome épidermoïde (SCC) soit le cancer buccal le plus répandu dans le monde, la forme géante de la maladie est extrêmement rare en raison de sa détection facile et de son diagnostic précoce. L'objectif principal de la chirurgie tumorale est l'excision avec des frontières claires de néoplasie. Le deuxième objectif est l'esthétique et la rétention fonctionnelle. L'approche chirurgicale spécifique est choisie en fonction de l'allongement, de l'épaisseur et de la localisation du défaut labial.

Rapport de cas. Les auteurs présentent le cas d'un patient atteint d'un carcinome épidermoïde de la lèvre inférieure. Dans le cas rapporté, le défaut d'épaisseur totale résultant de l'excision du SCC, qui affecte plus 
patient's demographic characteristics are considered. Poor social conditions are to be considered as a potential risk factor for the development of giant forms of SCC in addition. Improving the quality of life of these patients would be essential to minimize risk factors for the development of the disease and to improve prognosis overall.

Keywords: squamous cell carcinoma, lower lip, Bernard-Webster flap.

\section{INTRODUCTION}

The 2005 World Health Organization (WHO) classification of head and neck tumors distinguishes different types of squamous cell carcinoma (SCC): conventional, verrucous, basaloid, papillary, sarcomatous, acantholytic, adeno-squamous, cuniculatum. SCC can be well-, moderately- or poorly differentiated, and either keratinizing or non-keratinizing ${ }^{1}$. Conventional type SCC is characterized by squamous differentiation and invasive growth with disruption of the basement membrane. The majority of these occur on the lower lip because of its great exposure to precipitating factors ${ }^{2}$. Usually, in the initial stages it is painless and can go unnoticed. Percentages of morbidity and mortality in males are 6.6/100,000 and 3.1/100,000 respectively, while in females the same percentages are 2.9/100,000 and 1.4/100,0003. SCC of the lower lip occurs most frequently in male patients who have been exposed to sunlight for a long period of time.

Sunlight is considered as the most important etiopathogenetic factor. This type of tumor may also manifest in the unexposed areas of the body, suggesting that other factors also play a role in pathogenesis. SCC is thought to be the result of genetic damages to flat epithelial cells, leading to malignant transformation. Concomitant factors, such as variable genetic predisposition, prolonged exposure to tobacco and alcohol, a number of viruses, and suppression of immunity can all facilitate these genetic predispositions ${ }^{4}$. d'un tiers de la longueur de la lèvre inférieure, avait été reconstruit avec le flambeau Bernard-Webster.

Conclusions. Bien que les facteurs étiologiques de la manifestation du carcinome épidermoïde soient bien connus, de nouveaux facteurs pronostiques pour la différenciation tumorale, tels que l'expression anormale de la $\beta$-caténine, et l'impact négatif sur les caractéristiques démographiques des patients sont pris en compte. De mauvaises conditions sociales doivent également être pris en considération comme un facteur de risque potentiel pour le développement de formes géantes de CSC. L’amélioration de la qualité de vie de ces patients serait essentielle pour minimiser les facteurs de risque de développement de la maladie et améliorer le pronostic global.

Mots-clés: carcinome épidermoïde, lèvre inférieure, lambeau Bernard-Webster.

\section{Case presentation}

A 86-year-old female was admitted with 3-year history of tumor of the lower lip. Clinical examination revealed the presence of wide, dark formation located in the lateral portion of the lower lip without compromising the mouth commissure (Fig. 1-3). The clinical examination of the skin for concomitant lesions did not reveal any changes. The patient underwent incisional biopsy under local anesthesia (Fig. 4). A moderately differentiated, keratinized squamous cell carcinoma of lower lip, infiltrating the underlying skeletal muscle, was diagnosed after the histopathological exam. A computed tomography (CT) scan of head and neck (Fig. 5) revealed a normal configuration of the soft tissues of neck and cervical segment of the spine. The salivary glands showed no abnormalities. The muscles forming the floor of the mouth were symmetrical and well presented. The neck muscles were normal. No lymph-adenomegaly was detected. Thus, the staging was T2NOMO, according to the TNM system. The treatment of choice for SCC of the lower lip should be radical excision surgery with clear microscopic margins of neoplasia ${ }^{5}$. The patient's file was reviewed by an Oncology Committee. The treatment included single modality surgery without radio- and chemotherapy. With one surgical intervention, the lower lip cancer was removed and the defect reconstructed (Fig. 6,7). No secondary surgical procedures were required. The final postoperative result is shown in Fig. 8.

\section{Discussion}

We presented the case of a patient with a squamous cell carcinoma of the lower lip, pointing out the 


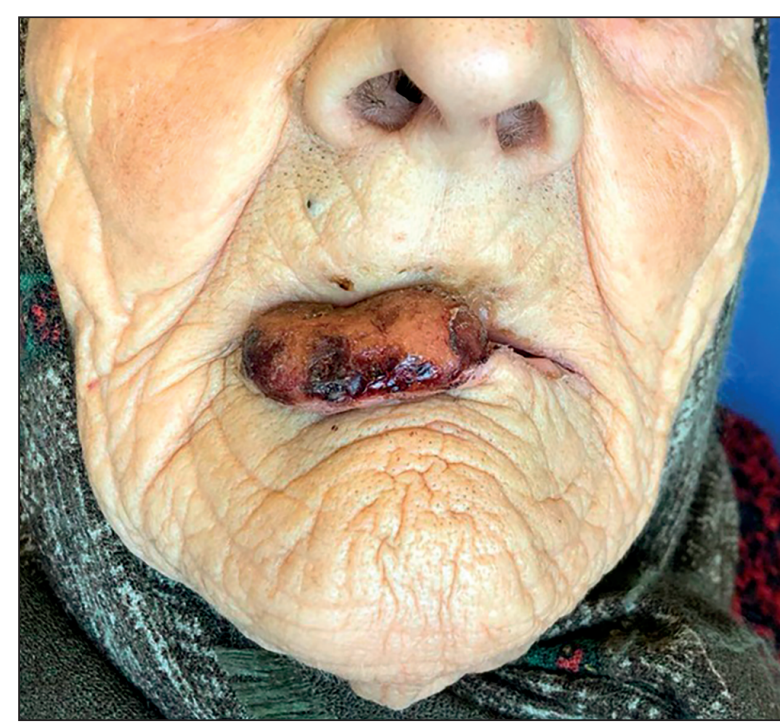

Figure 1. Lower lip tumor at hospital admission (front view).

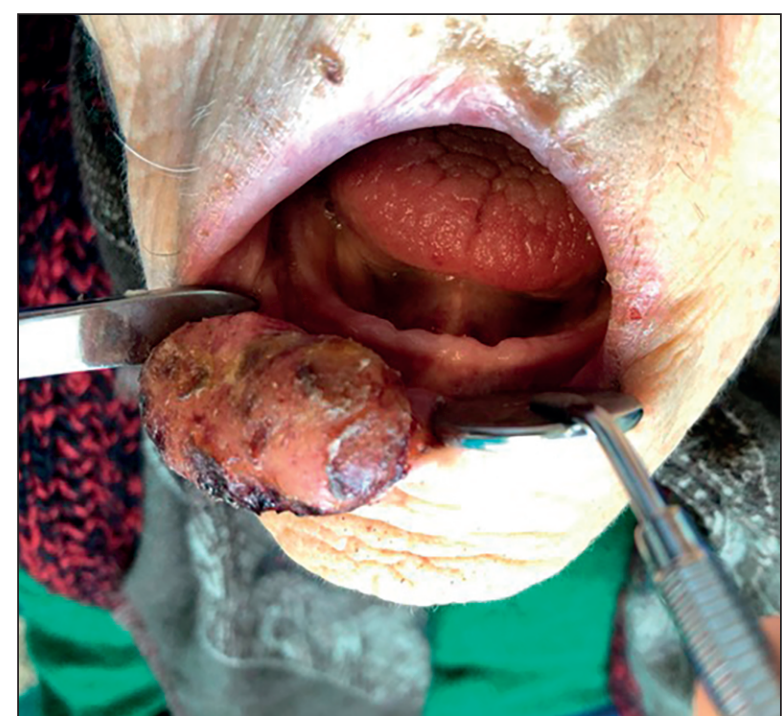

Figure 3. Intraoral view of the tumor.

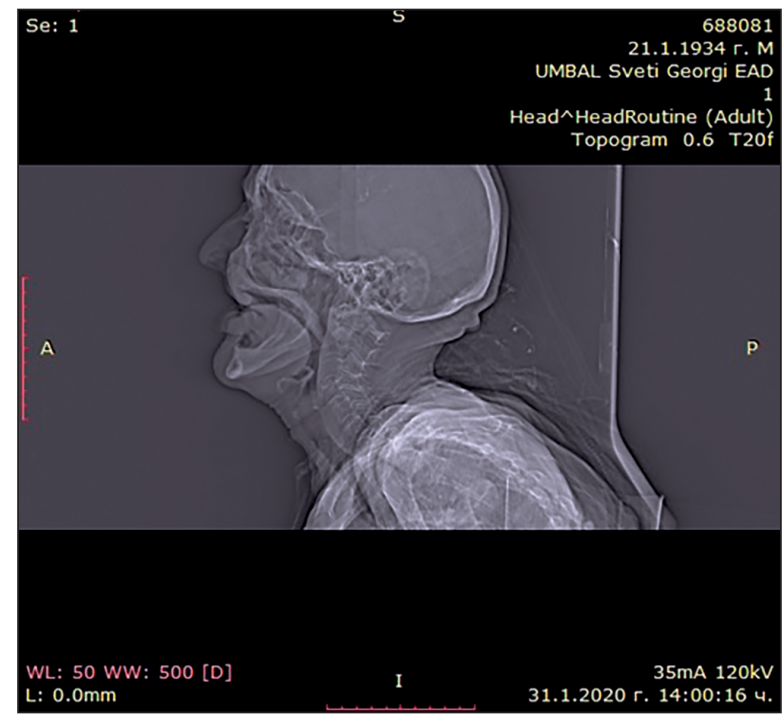

Figure 5. Head and neck computed tomography (CT) scan of the patient.

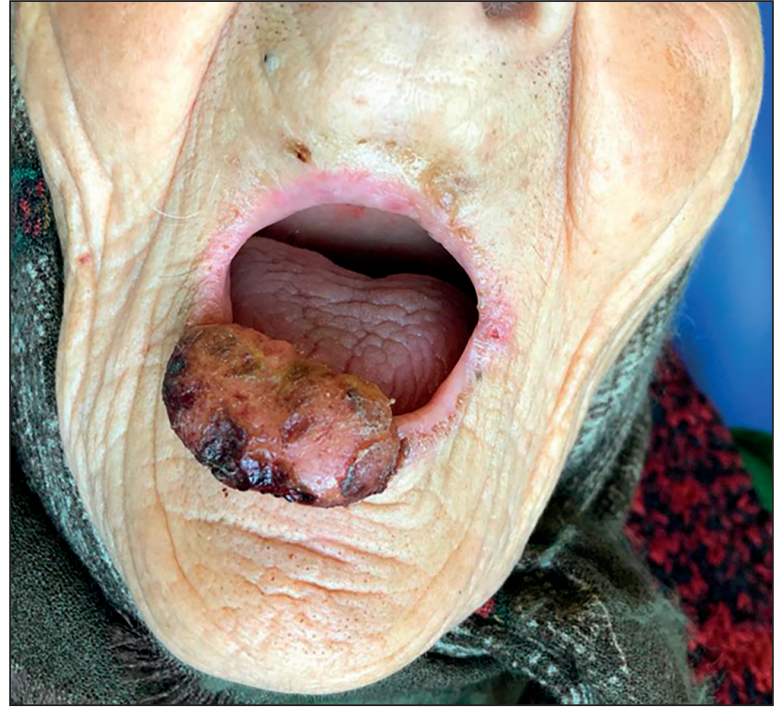

Figure 2. Lower lip tumor (front view).

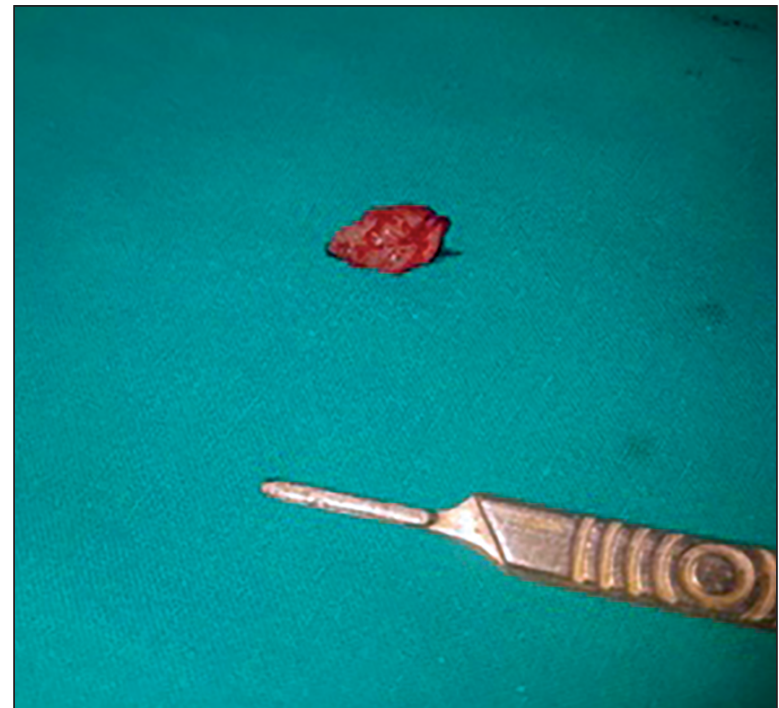

Figure 4. Incisional biopsy was performed.

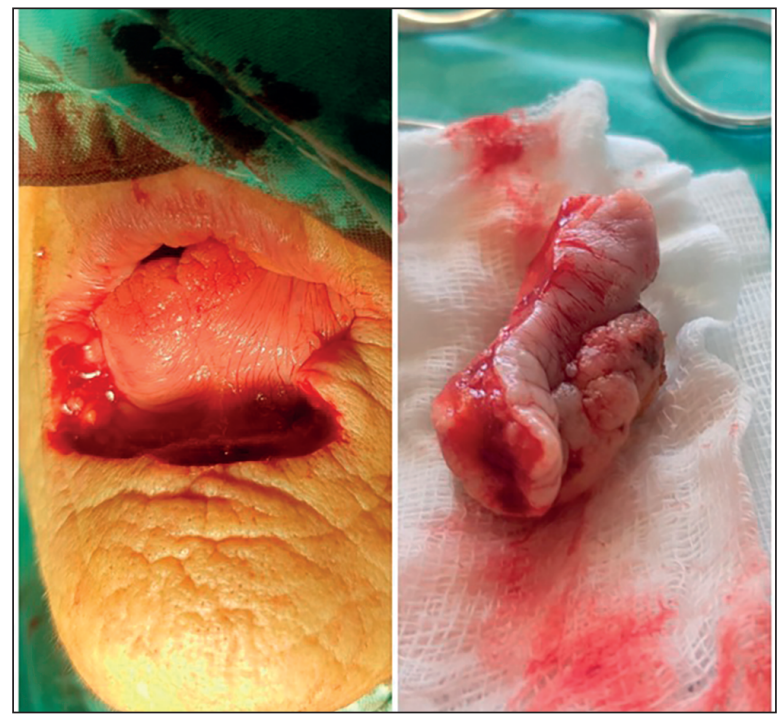

Figure 6. The patient underwent a complete excision of the tumor and resection of the lower lip. 


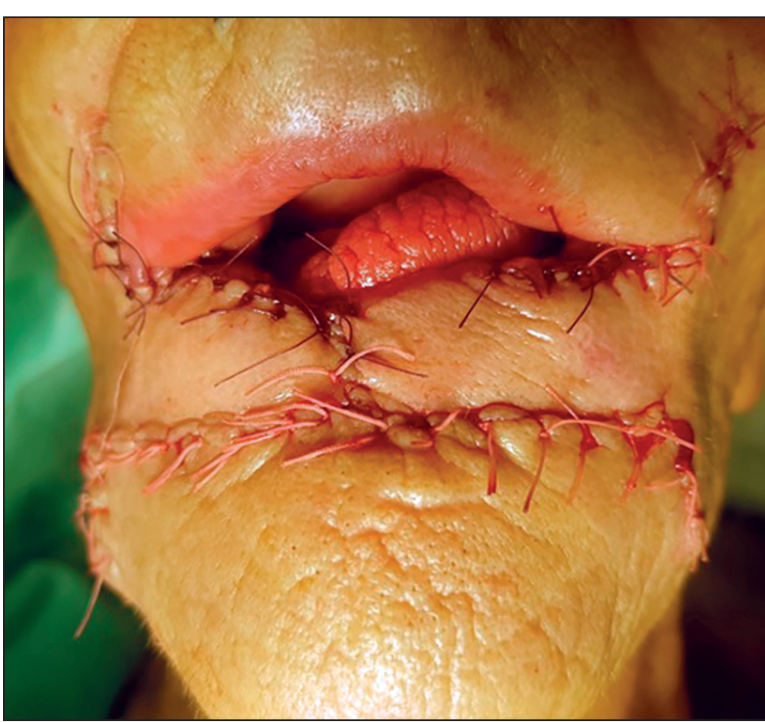

Figure 7. Immediate postoperative photograph.

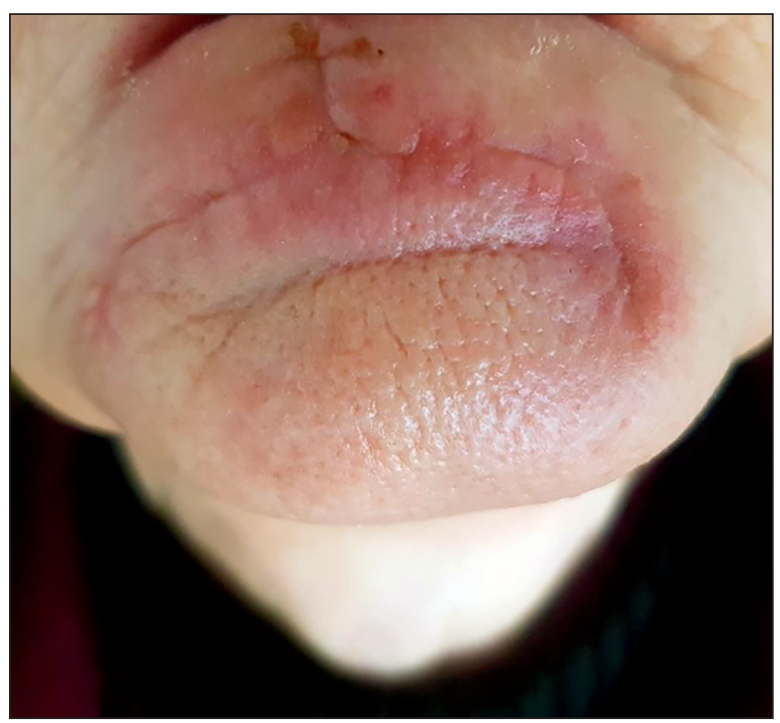

Figure 8. Postoperative result after suture removal. importance of early detection and complete surgical removal of such tumors. This case suggests a higher prognostic significance of the size of the lower lip cancer, as well as the infiltration in tumor-surrounding tissue, than the degree of its histological differentiation for the development of metastatic changes in patients. Tumor size is a prognostic factor for recurrence and regional metastasis. The risk increases 2.8 times with increasing of lip SCC size over $2 \mathrm{~cm}$ in diameter ${ }^{6}$.

In the case of lower lip lesions involving one to two thirds, the methods of Abbe-Estlander, Karapandzic, Bernard-Webster, Bernard-Burrow are used. For major lesions involving more than two-thirds, reconstruction using the Webster-Bernard method, the Gillies method, and other methods described for lower lip reconstruction could be performed ${ }^{7}$. In many advanced primary or recurrent/ persistent tumors after radiation treatment, vascular-free soft tissue or composite-free vascularized lamp are used for block resection of the lower lip and mandible ${ }^{8}$. Lower lip cancer has low metastatic potential, with cervical metastases reported in 10-15-20\% of cases ${ }^{9}$. It is accepted that oral cancer does not require prophylactic cervical dissection, because the incidence of occult metastases is low and only $5-10 \%$ of cases develop metastases during the disease ${ }^{9}$.

The primary aim in tumor surgery is excision with clear neoplasia margins. Aesthetics and preservation of function are secondary goals. Modern surgical treatment aims at maximum radicalism. The specific surgical approach should be selected according to lip defect extension, thickness and location $^{10,11}$. In our case, the full-thickness defect resulting from excision of SCC, that affects more than one third of the length of the lower lip, was reconstructed using Bernard-Webster flap. The potential disadvantages of the Bernard-Webster flap include the incision notch in the region of the lower lip and effacement of the gingivobuccal sulcus ${ }^{12}$. It also requires care in setting tension of lower lip to maintain oral competence, because it is an adynamic reconstruction. We monitored the patient for approx. 20 months and analyzed the result of the surgical procedure. The reconstructed lower lip had satisfactory volume and definition. The patient was able to restart her usual diet 30 days after the surgical intervention. The mouth-opening circumference was maintained. In the postoperative period, the patient did not report hypoesthesia or anesthesia in the perioral area and she was pleased with her late functional Results. There was no recurrence or new skin lesions in the perioral region during the postoperative follow-up. Thus, the modified Bernard-Webster flap proved to be an excellent alternative to repair full-thickness lower lip defects with more than $1 / 3$ of the lower lip length, as it could be performed in one stage, it allowed the use of similar adjacent tissues, and the result was functionally efficient. Finally, it is important to emphasize that the early diagnosis remains a key element for the therapy of SCC.

\section{Conclusions}

Although the etiologic factors for squamous cell carcinoma are well-known, new prognostic factors for tumor differentiation, such as $\beta$-catenin abnormal expression, and the negative impact on patient demographic characteristics are considered. Moreover, 
poor social conditions must be considered as a potential risk factor for the development of giant forms of SCC. Improving the quality of life of these patients would be essential to minimize risk factors for the development of the disease and to improve prognosis overall.

\section{Author Contributions:}

M.C., A.B., and I.A. were responsible for the diagnostic procedures, clinical diagnosis, and treatment decisions. M.C. and M.B. wrote the manuscript. All authors have read and agreed to the published version of the manuscript.

\section{Compliance with Ethics Requirements:}

„The authors declare no conflict of interest regarding this article"

„The authors declare that all the procedures and experiments of this study respect the ethical standards in the Helsinki Declaration of 1975, as revised in 2008(5), as well as the national law. Informed consent was obtained from the patient included in the study"

"No funding for this study"

\section{Acknowledgments:}

\section{None}

\section{References}

1. Barnes L, Eveson JW, Reichart P, Sidransky D. Pathology and genetics of head and neck tumors. World Health
Organization Classification of Tumors. IARC Press, Lyon. 2005

2. Vukadinovic M, Jezdic Z, Petrovic M, Medenica LM, Lens M. Surgical management of squamous cell carcinoma of the lip: analysis of a 10-year experience in 223 patients. J Oral Maxillofac Surg. 2007; 65(4):675-9.

3. Mehrotra R, Yadav S. Oral squamous cell carcinoma: etiology, pathogenesis and prognostic value of genomic alterations. Indian J Cancer. 2006; 43:60-6.

4. Dumitras IC, Ionescu C, Bartos D, Diaconu C. The diagnosis of malignant disease: sometimes a matter of pure chance. Arch Balk Med Union 2017;52(1):112-116.

5. Akcam TM, Gubisch W, Unlu H. Nonmelanoma skin cancer of the head and neck: surgical treatment. Facial Plast Surg Clin North Am. 2012;20(4):455-71.

6. Golubović M, Asanin B, Jelovac D, Petrović M, Antunović M. Correlation between disease progression and histopathologic criteria of the lip squamous cell carcinoma. Vojnosanit Pregl. 2010;67(1):19-24.

7. National Comprehensive Cancer Network (NCCN), Guidelines Version 1. 2015 Head and Neck Cancers. Available at: www.nccn.org (accessed 02 March 2020)

8. Mistry RC, Qureshi SS, Kumaran C. Post-resection mucosal margin shrinkage in oral cancer: quantification and significance. Journal of Surgical Oncology. 2005;91:131-133.

9. Proffitt SD, Spooner TR, Kosek JC. Origin of undifferentiated neoplasm from verrucous epidermal carcinoma of oral cavity following radiation. Cancer. 1970; 26: 389.

10. Eskiizmir G, Baker S, Cingi C. Nonmelanoma skin cancer of the head and neck: reconstruction. Facial Plast Surg Clin North Am. 2012;20(4):493-513.

11. Ebrahimi A, Maghsoudnia GR, Arshadi AA. Maghsoudnia GR, Arshadi AA. Prospective comparative study of lower lip defects reconstruction with different local flaps. J Craniofac Surg. 2011;22(6):2255-9.

12. Baumann D, Robb G. Lip reconstruction. Semin Plast Surg. 2008;22(4):269-80. 